\title{
Specific Detection of Potato Virus A in Dormant Tubers by Reverse-Transcription Polymerase Chain Reaction
}

Rudra P. Singh and Mathuresh Singh, Agriculture and Agri-Food Canada, Potato Research Centre, P.O. Box 20280, Fredericton, New Brunswick, E3B 4Z7, Canada

\begin{abstract}
Singh, R. P., and Singh, M. 1998. Specific detection of potato virus A in dormant tubers by reverse-transcription polymerase chain reaction. Plant Dis. 82:230-234.

A reverse-transcription polymerase chain reaction (RT-PCR) protocol was developed for the detection of potato virus A (PVA) in dormant tubers. A 255-bp amplified product was produced using a primer pair from the P1 gene of the PVA genome. The 255-bp product was detected in nucleic acids from leaves, tubers, and purified virions and was specific to PVA as determined by Southern blot tests and detection by a PVA-specific probe. When presented with seven potato virus/strain nucleic acids and a viroid, singly and in mixed infections, the primer pair did not amplify any products. Its specificity to PVA was further demonstrated by RT-PCR detection of PVA from the known mixtures of PVA and potato virus Y samples. PVA was detected in foliage nucleic acids at a dilution of 1:1024-1:4096 and tuber nucleic acids at 1:256-1:1024. It was uniformly present in various parts of the potato tuber. PVA was detected in composite tuber samples containing a ratio of infected to healthy sap of 1:29 and was readily detected in tubers of several cultivars or breeding lines, in dormant as well as in sprouting tubers stored at 20$25^{\circ} \mathrm{C}$ for 4 months.
\end{abstract}

Additional keywords: potyviruses, sensitivity

Potato virus A (PVA), a member of the genus Potyvirus, occurs worldwide, infects many potato cultivars, and can cause yield losses of about $40 \%$ (1). PVA causes mild mosaic symptoms in most potato cultivars and in combination with potato virus $\mathrm{X}$ (PVX), it can cause a severe disease known as "potato crinkle" (9). Combination of potato virus Y (PVY) and PVA also results in severe mosaic symptoms. PVA, like PVY, is spread in the field by various species of aphids. Although PVA occurrence is sporadic, incidences of $9-11 \%$ are not uncommon in certain cultivars $(10,18)$.

Virus concentration in infected plant tissue is low and the virions are weakly immunogenic (2). Therefore, reliable antisera lacking cross-reactivity to other potyviruses are not readily available. PVA has not been reliably detected from the primarily infected tubers either in the dormant stage or after the natural break of dormancy. Its detection by enzyme-linked immunosorbent assay (ELISA) requires an artificial break of dormancy and secondarily infected tubers (26). Therefore, there is a need for a specific method of PVA detection in general and for detection of the virus in dormant tubers in particular.

Corresponding author: R. P. Singh; 506/452-3260; Fax 506/452-3316

E-mail: singhr@em.agr.ca

Accepted for publication 4 November 1997.

Publication no. D-1997-1212-01R

(C) 1998 The American Phytopathological Society
In recent years, polymerase chain reaction (PCR) has become the preferred method of pathogen detection because it provides a way to exponentially amplify specific DNA sequences by in vitro DNA synthesis. Depending on the choice of primers, PCR can provide both narrow and broad specificities for various isolates or strains of pathogens $(6,7)$. For the detection of RNA, a complementary DNA (cDNA) is synthesized by reverse transcription (RT) and then amplified with PCR. For potyviruses, the RT-PCR has been used for group specificity $(3,5,8)$ and for the identification of individual viruses $(4,14,24,27)$. However, PVA has not been included in any of these studies.

We have been involved in the development of RT-PCR protocols for the detection of potato viruses and viroids in dormant tubers or in aphids $(12,14,16,19,22)$. This study extends that objective. We report a specific RT-PCR method for the detection of PVA in tubers and other plant tissues.

\section{MATERIALS AND METHODS}

Virus cultures and inoculation method. An isolate of PVA obtained from commercial potato fields in New Brunswick, Canada, and used in previous studies $(17,23)$ was maintained in Nicandra physaloides (L.) Gaertn. and Russet Burbank potato plants. Inoculum from infected leaves was prepared in a buffer solution (0.01 M sodium phosphate containing $0.4 \%$ sodium sulfite, $\mathrm{pH} 7.5$ ). PVA virions were purified from infected leaves by a previously used method (23). Virus-free plantlets of potato cvs. GoldRush, Green Mountain, Russet Burbank, and Shepody from the Plant Propagation Centre (New Brunswick Department of Agriculture and Rural Development, Fredericton, Canada) were grown in a greenhouse. Additional field-grown tubers of Bake King, F34011, F58050, and K113-1 infected with PVS and PVX were also used for the production of PVA-infected tubers. To optimize PVA infection of tubers, potato plants were topgrafted with PVA-infected scions. Plants were assayed by ELISA (23) 30 and 60 days post-grafting, and tubers were harvested 90 days post-grafting and tested within 2-3 weeks (dormant), followed by testing at 2 and 4 months after storage at $20-25^{\circ} \mathrm{C}$.

Potato viruses $\mathrm{M}$ (PVM), S (PVS), $\mathrm{X}$ $(\mathrm{PVX}), \mathrm{Y}^{\mathrm{O}}\left(\mathrm{PVY}^{\mathrm{O}}\right), \mathrm{Y}^{\mathrm{N}}\left(\mathrm{PVY} \mathrm{Y}^{\mathrm{N}}\right), \mathrm{Y}^{\mathrm{NTN}}$ $\left(\mathrm{PVY}^{\mathrm{NTN}}\right)$, leaf roll (PLRV), and potato spindle tuber viroid (PSTVd) from our own collection were used to test the specificity of the PVA primers. PVY strains were tested using 5-12 different isolates of each strain group. To determine whether PVA can be specifically detected in the presence of $\mathrm{PVY}^{\mathrm{O}}$, leaves from 12 Shepody potato plants infected with different isolates of $\mathrm{PVY}^{\mathrm{O}}$, differing in host reactions and severity (19) and mixed with PVA-infected leaves of Russet Burbank plants, were tested by RT-PCR for PVA and $\mathrm{PVY} \mathrm{O}^{\mathrm{O}}$ detection.

Nucleic acid extraction from potato leaves, sprouts, and tubers. Tuber sap, three drops from the bud end, and three drops from the stem end were collected in a microcentrifuge tube, using a tuber slicer (Electrowerk, Behcke and Co., Hanover, Germany). Potato leaf or sprout sap (six drops) were similarly collected in microcentrifuge tubes. Nucleic acids were extracted (13) with some modifications (14). The modified procedure consisted of mixing $150 \mu \mathrm{l}$ of the tuber, leaf, or sprout tissue sap with $300 \mu \mathrm{l}$ of the extraction buffer (0.1 M Tris-HCl, pH 7.4, $2.5 \mathrm{mM}$ $\mathrm{MgCl}_{2}$ ), containing 6 units of RNase-free DNase I (Bohringer Mannheim). This mixture was incubated at $37^{\circ} \mathrm{C}$ for $10 \mathrm{~min}$, then $200 \mu \mathrm{g}$ of proteinase $\mathrm{K}$ (Promega, Madison, WI) and 1\% sodium dodecyl sulfate (SDS) were added and incubated for an additional $10 \mathrm{~min}$ at $65^{\circ} \mathrm{C}$. Nucleic acid extraction with phenol-chloroformisoamyl alcohol $(25: 24: 1)$ in equal volumes of nucleic acid extraction solution and 
organic solvents followed. The emulsion was centrifuged $(15 \mathrm{~min}, 12,000 \times \mathrm{g}$ at $4^{\circ} \mathrm{C}$ ) and nucleic acids were precipitated with equal volume of isopropanol containing sodium acetate $(10 \mu \mathrm{l}$ of $3 \mathrm{M}$ per $100 \mu$ of isopropanol) (14). The precipitate was collected by centrifugation $(15 \mathrm{~min}$, $12,000 \times g$ ), dried under vacuum, and dissolved in $20 \mu \mathrm{l}$ (tuber and sprouts) or $100 \mu \mathrm{l}$ (leaves) of sterile water. These stocks were termed as undiluted nucleic acid preparations. For sensitivity of detection this stock was further diluted four-fold up to 1:4096 (leaves) and up to 1:1024 (tubers).

To study the distribution of virus in the tuber (17), nucleic acid extraction was done on parts of tubers consisting of predominantly epidermal layer, tissues from cortical zones containing cortical parenchyma, and tissues around the pith, bud end, stem end, and sprouts, using 20 tuber replicates.

For the composite samples (20), PVA containing tuber sap was mixed with sap from noninfected tubers in a ratio of 1:4, $1: 9,1: 14,1: 19,1: 29$, and $1: 39$ prior to nucleic acid extraction.

cDNA synthesis and PCR amplification. The primer pairs were selected on the basis of specificity to PVA sequences and discrimination to the other potato virus sequences, using the FastA program of the Genetics Computer Group (GCG) (University of Wisconsin). The forward primer (5'-GTTGGAGAATTCAAGATCCTGG-3') homologous to nucleotides (nt) 183-204, and the reverse primer $\left(5^{\prime}\right.$-TTTCTCTGCCACCTCATCG-3') complementary to $\mathrm{nt}$ 437-419 for the PVA P1 gene sequence (11) were designed using the Primer Version 0.5 program (Whitehead Institute). The primers were synthesized using a

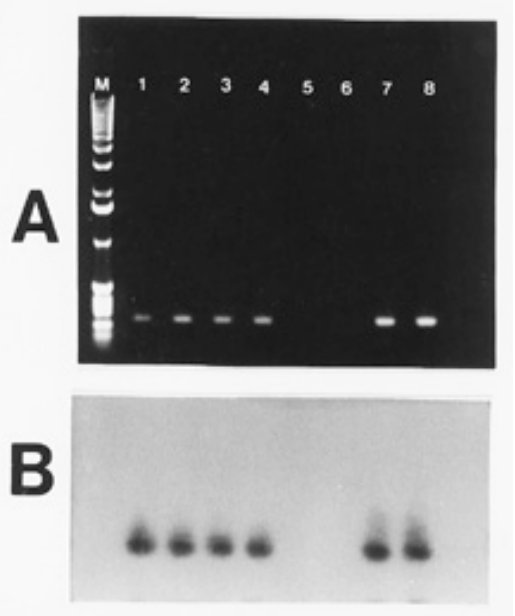

Fig. 1. (A) Agarose gel electrophoresis and (B) Southern blot hybridization with digoxigeninlabeled potato virus A (PVA)-cDNA probe of reverse transcription polymerase chain reaction products of PVA-infected samples. Lanes M, size markers; lanes 1-2, leaves; lanes 3-4, tubers; lanes 5-6, negative controls; and lanes 7-8, purified PVA-RNA extracts. The 255-bp product is specific to PVA (arrow).
PCR-Mate DNA synthesizer (Applied Biosystems, Foster City, CA).

For reverse transcription, $1 \mu \mathrm{l}$ of nucleic acids was added to a $20-\mu 1$ reaction mixture. The rest of reverse transcription and the PCR procedure was the same as in Singh and Singh (14) except that the amount of Amplitaq DNA polymerase used was 1.25 units and the amplification was carried out in 30 cycles using a Peltier thermal cycler (PTC-200, MJ Research, Watertown, MA). Each cycle consisted of $1 \mathrm{~min}$ duration of denaturation at $94^{\circ} \mathrm{C}$, primer annealing at $60^{\circ} \mathrm{C}$, and primer extension at $72^{\circ} \mathrm{C}$. Ten $\mu \mathrm{l}$ of amplified product was electrophoresed in a $1.5 \%$ agarose gel containing $0.5 \mu \mathrm{g} / \mathrm{ml}$ ethidium bromide and photographed. One track contained a 1 kb DNA ladder (Gibco, BRL, MD) to determine the size of the amplified products.

Evaluation of the field-collected leaf samples of RT-PCR. Thirty samples of potato leaves from the 1997 growing season, collected by the Idaho Crop Improvement Association, were mailed to the Fredericton Research Centre on 24 July and 7 August 1997. The leaves in the first batch were mostly brown on arrival. Thirty-six leaves from Cavendish Farms, Summerside, Prince Edward Island, were received on 16 July 1997. The samples from both groups were coded. Their identity and virus content were unknown to us. The samples were tested by RT-PCR and results were forwarded to respective places within 1 week.

\section{RESULTS}

Amplification of the PVA-specific product. The primer pair selected from the P1 gene sequence of the PVA genome amplified a product of $255 \mathrm{bp}$ (Fig. 1A). The product was amplified from nucleic acid preparations of infected leaves (lanes 1-2), tubers (lanes 3-4), and purified virions (lanes 7-8). No amplified product was observed with plant tissues not infected with PVA (Fig. 1A, lanes 5-6). The specificity of the amplified product to PVA was confirmed by a PVA molecular probe after Southern blot transfer of PCR products (Fig. 1B, lanes 1-8).

Nucleic acid preparations containing PVM, PVS, PVX, PVY ${ }^{\mathrm{O}}, \mathrm{PVY}^{\mathrm{N}}$, $\mathrm{PVY}^{\mathrm{NTN}}$,
PLRV, and PSTVd and subjected to RTPCR amplification with a PVA primer pair did not yield any amplified product (data not shown). In addition, PVA was specifically identified from leaf and tuber samples of potato cultivars and breeding lines (F34011, F58050, and K113-1) simultaneously infected with PVS + PVX and PVA (Table 1). The presence of PVA and other viruses in these samples were determined by ELISA tests. There was almost $100 \%$ correlation with ELISA and RT-PCR detection from leaf extracts (Table 1).

RT-PCR of PVA and PVY from mixed leaf samples. Specific detection of PVA in mixed samples with the closely related potyvirus, $\mathrm{PVY}^{\mathrm{O}}$, was studied. As shown (Fig. 2, lanes 1-12, lower panel), a 255-bp product specific to PVA and a 480bp product for $\mathrm{PVY}^{\mathrm{O}}$ (21) (Fig. 2, lanes 112, upper panel) were detected. There was no indication of any extra bands for PVA indicative of cross-amplification, and no bands were obtained with uninfected samples (Fig.2, lanes 13-16).

Sensitivity of RT-PCR detection in leaves and tubers. Nucleic acid extracts from leaves and tubers diluted fourfold up to 1:4096, prior to the RT-PCR amplification, showed that PVA was reliably detected in leaves up to 1:1024 dilution and faintly up to 1:4096 from leaf extracts (Fig. $3 \mathrm{~A}$, lanes $13-15$ and 16-18, respectively) and in tubers up to $1: 256$ and in some samples up to $1: 1,024$ (Fig. 3B, lanes 13-15 and 16-18). Results were similar with three different leaves or tuber extracts (Fig. 3A,B).

Application of methods to dormant tubers. Primarily infected tubers of eight cultivars and breeding lines were tested in the dormant stage as well as after 2 and 4 months of storage. PVA infection was detected in $100 \%$ of tubers from susceptible cultivars and breeding lines (Table 1). None of the tubers of cvs. Bake King or Shepody were infected with PVA. Both Bake King and Shepody are highly resistant to PVA (unpublished data). Storage of tubers at $20-25^{\circ} \mathrm{C}$ for 2 and 4 months did not reduce the detection of PVA in susceptible cultivars (Table 1). Some tubers had sprouted at this stage.

Distribution of PVA in different tuber parts with three different tubers showed

Table 1. Detection of potato virus A (PVA) by reverse-transcription polymerase chain reaction (RTPCR) from potato cultivars and breeding lines in the presence of potato viruses S (PVS) and X (PVX)

\begin{tabular}{lccccc}
\hline & \multicolumn{2}{c}{ Leaves Cultivars and viruses $^{\mathbf{a}}$} & & & \multicolumn{2}{c}{ Tubers } \\
\cline { 2 - 3 } \cline { 5 - 6 } & ELISA & RT-PCR & & Dormant & Sprouted (4mo) \\
\hline Bake King-PVA & $0 / 10$ & $0 / 10$ & & $0 / 24$ & $0 / 24$ \\
F34011-PVA, PVS, PVX & $10 / 10$ & $10 / 10$ & & $21 / 21$ & $21 / 21$ \\
F58050_PVA, PVS, PVX & $10 / 10$ & $10 / 10$ & & $16 / 16$ & $13 / 13$ \\
GoldRush-PVA & $15 / 16$ & $16 / 16$ & & $40 / 40$ & $20 / 20$ \\
Green Mountain-PVA & $20 / 20$ & $20 / 20$ & & $40 / 40$ & $20 / 20$ \\
K113-1-PVA, PVS, PVX & $10 / 10$ & $10 / 10$ & & $32 / 32$ & $32 / 32$ \\
Russet Burbank-PVA & $25 / 25$ & $25 / 25$ & & $40 / 40$ & $20 / 20$ \\
Shepody-PVA & $0 / 55$ & $0 / 55$ & & $0 / 70$ & $0 / 50$ \\
\hline
\end{tabular}

a The cultivars tested were graft inoculated with PVA infected scions and the designation "Bake King-PVA" and "Shepody-PVA" does not indicate that these plants were infected with PVA. 
that the virus was uniformly distributed in sprouts (Fig. 4A, lanes 1-3); bud end (lanes 4-6); stem end (lanes 7-9); and tissues consisting of mainly epidermis (Fig. 4B, lanes 1-3), cortex (lanes 4-6), and pith (lanes 7-9). Repeat tests at 30 days apart did not show any reduction either in the intensity of the bands or in the number of positive samples.

Composite samples of PVA-infected and healthy tuber sap in ratios of 1:4, 1:9, 1:14, $1: 19,1: 29$, and 1:39 showed that a PVAspecific PCR product was regularly detected at a ratio of infected to healthy of
1:29 (Fig. 5, lanes 13-15). Results are presented depicting three samples. Occasionally bands with variable intensity were also observed with some samples at the ratio of 1:39 (Fig. 5, lanes 16-18).

Application to field-collected leaf samples. Of the 30 leaf samples from Idaho, 5 contained PVA, 17 PVY, and 7 were negative for both viruses. These results were in agreement when retested with ELISA. There were no differences between the PCR bands observed with nucleic acids obtained from brown or green leaf samples. Of the 36 samples from Cavendish
Farms, 30 were negative for PVA and PVY and 6 contained PVY alone. After the test it was learned that 24 leaves were from Shepody (highly resistant to PVA), 6 from PVY infected plants, and 6 from healthy controls. The Shepody samples were previously diagnosed to be infected with PVA when tested by ELISA.

\section{DISCUSSION}

In this study, we report an RT-PCR protocol for the detection of PVA in potato tubers, sprouts, and foliage. The amplified product is specific to PVA and the primer

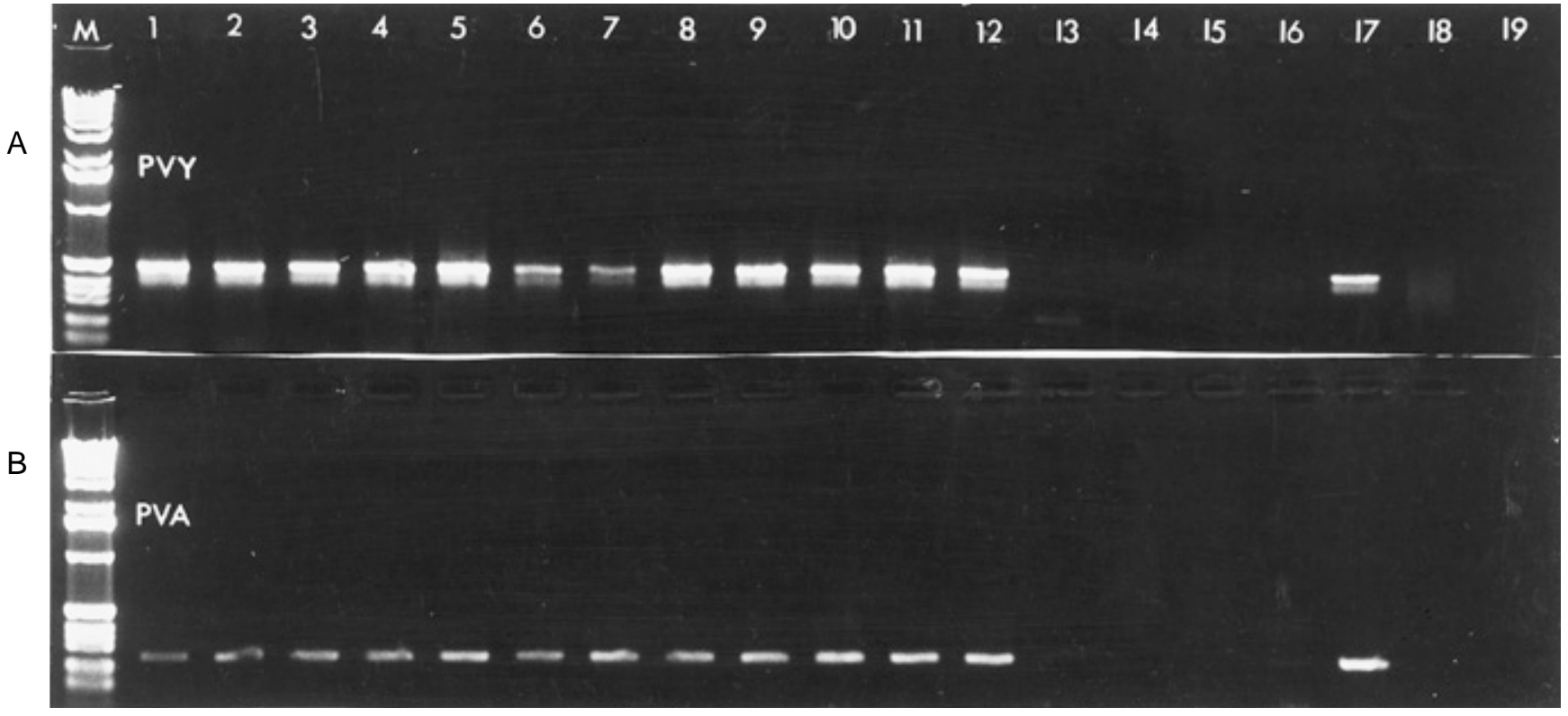

Fig. 2. Specific detection of potato virus A (PVA) from mixed leaves infected with PVA and 12 different PVYO isolates by reverse transcription polymerase chain reaction. (A) Lanes 1-12, 480 bp PVYO product. (B) Lanes 1-12, 255 bp PVA product; lanes 13-16, uninfected potato leaves; lane 17 contains positive controls for $\mathrm{PVY} \mathrm{Y}^{\mathrm{O}}$ and PVA, respectively; and lanes 18-19 contain a PCR mix without template. M is the size marker.

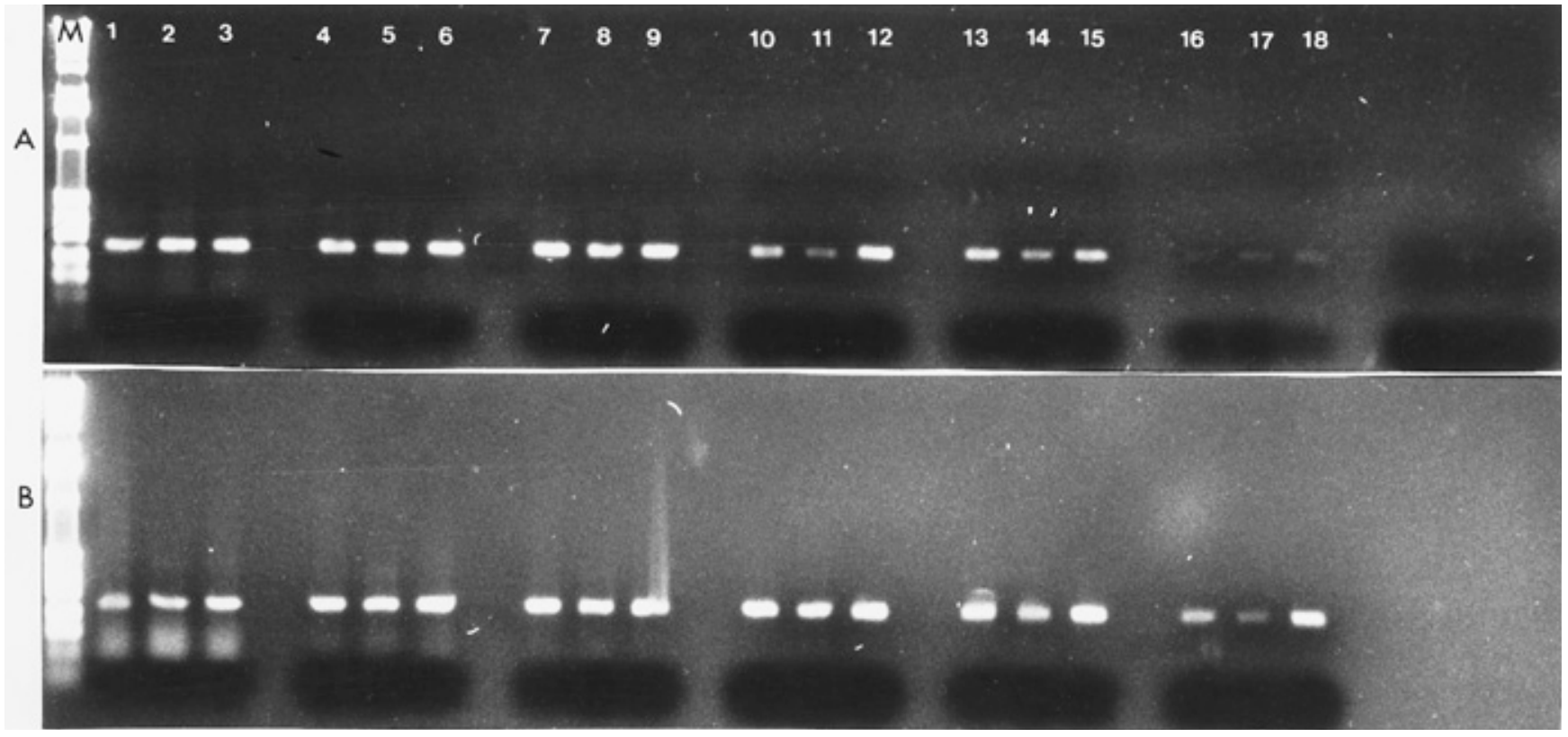

Fig. 3. Sensitivity of potato virus A (PVA) detection by reverse transcription polymerase chain reaction in leaves (A) and tubers (B). A, three different leaf nucleic acids were diluted to 1:4 (lanes 1-3); 1:16 (lanes 4-6), 1:64 (lanes 7-9), 1:256 (lanes 10-12), 1:1024 (lanes 13-15), 1:4096 (lanes 16-18). B, three different undiluted tuber nucleic acids (lanes 1-3), 1:4 (lanes 4-6), 1:16 (lanes 7-9), 1:64 (lanes 10-12), 1:256 (lanes 13-15), and 1:1024 (lanes 16-18). M is the size marker. 
pair does not amplify any product from commonly encountered potato viruses and PSTVd. For the choice of primer pairs, three considerations were made. The primers were from the P1 protein gene of PVA genome, which has the least homology with P1 proteins of the other potyviruses (11); the primers were from the N-terminal one-third portion of the $\mathrm{P} 1$ protein gene of any sequences with PVM, PVX, PVY and $\mathrm{PVY}^{\mathrm{N}}$. However, seven middle bases of forward primer did share homology with PVY ${ }^{\mathrm{NTN}}$, based on FastA analysis of the GCG program. Third, the size of the amplified product was restricted to between 200 and $400 \mathrm{bp}$, a size range that is more sensitive than larger ones (16).

As reported on the basis of the indicator plants and ELISA tests, concentration of PVA in potato leaves and tubers is considerably lower than other potyviruses infecting potato. In the case of $\mathrm{PVY}^{\mathrm{O}}$, tuber extracts diluted to 1:4,096 produced regularly amplified fragments $(14,16)$. However, PVA was not detected beyond 1:1024 dilution in the tuber extracts of susceptible cultivars (Fig. 3B). As noted in PVYPVA, in which both primers did not share

infected plants (13), the concentration of the PVA is also lower in the tubers than in the leaves (Fig. 3B).

In contrast to the earlier reports of an erratic distribution of PVA in tubers (26), we found that dormant tubers of several cultivars and breeding lines contained similar amounts of PVA throughout the tubers (Fig. 4A,B), similar to a previously determined distribution of PVA in tubers by bioassay using Physalis angulata plants (17). The reasons for this discrepancy are not clear. Because of graft-inoculation of the plants in our study, there is a possibility of a build-up of high concentrations of virus. It has been shown that in cultivars with high $\mathrm{PVY}^{\mathrm{O}}$ concentrations, both budand stem-ends contain equal amounts of virus, while in cultivars with low concentrations of virus, either the bud or stem end contains the virus (14). However, in the case of PVA, field infected tubers have been found to contain virus throughout the tuber (17), similar to graft-inoculated in the present study.

The composite-sample size of PVA infected tissue combined with those of healthy tissue extracts indicates routine use

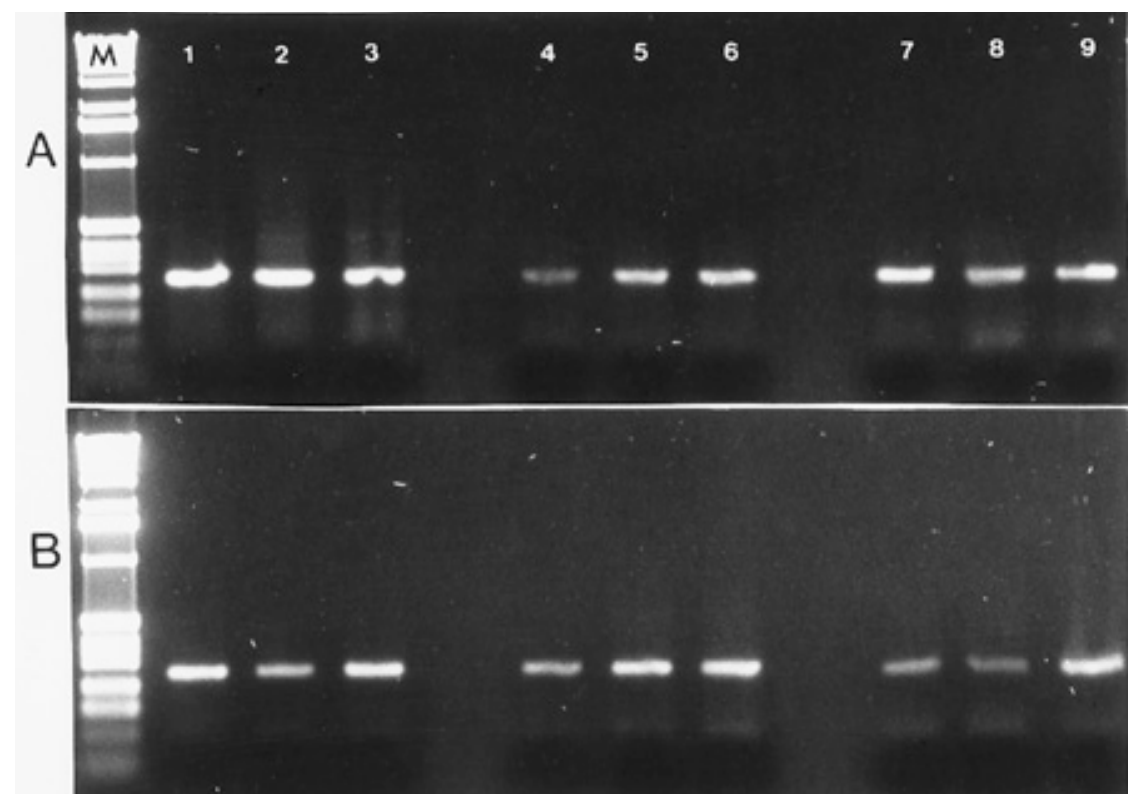

Fig. 4. Detection of potato virus A (PVA) from different parts of the tuber. (A) Sprouts (lanes 1-3), bud end (lanes 4-6), stem end (lanes 7-9); (B) Epidermal layer (lanes 1-3), cortical layer (lanes 4-6), and the pith tissues (lanes 7-9). Tuber parts were from three different tubers of Green Mountain. M is the size marker.

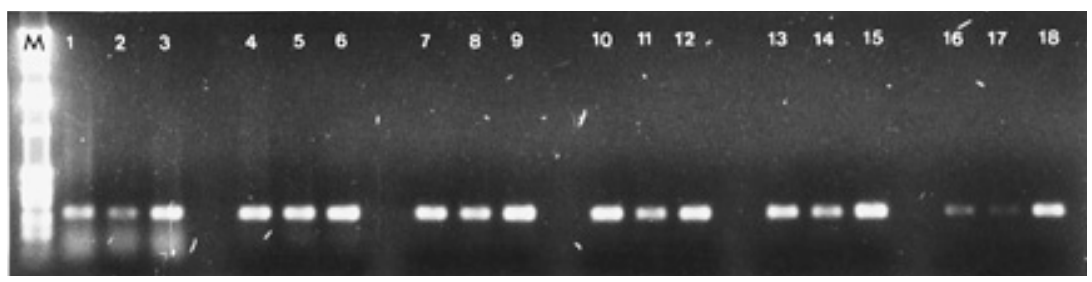

Fig. 5. Detection of potato virus A (PVA) in composite tuber samples of infected and healthy in ratios of 1:4 (lanes 1-3), 1:9 (lanes 4-6), 1:14 (lanes 7-9), 1:19 (lanes 10-12), 1:29 (lanes 13-15), and 1:39 (lanes 16-18). $\mathrm{M}$ is the size marker. of PVA in a 1 to 30 combination (Fig. 5). This observation is similar to the range of PVA infectivity detected in bioassays using P. floridana detached leaves, where $100 \%$ of the leaves showed lesions at the 1:10 combination, but decreased to $20 \%$ at the 1:50 combination (20). Detection of PVA from dormant tubers differed from that of $\mathrm{PVY}^{\mathrm{O}}$ in the inhibition of reaction with tuber extracts. PVA can be amplified by using undiluted tuber nucleic acids (Fig. 3B, lanes 1-3), although dilutions of nucleic acids to 1:4 always provided better amplification. In contrast, it has been difficult to detect $\mathrm{PVY}^{\mathrm{O}}$ from tuber nucleic acids of certain cultivars, because of substances, which inhibit RT-PCR reactions in undiluted nucleic acid extracts (14).

In conclusion, this study describes a RTPCR protocol that can be used to detect PVA from foliage, sprouts, and dormant tubers as easily as other potyviruses $(14,16)$ infecting potatoes.

\section{ACKNOWLEDGMENTS}

We thank Andrea Dilworth and Tom Somerville for providing technical assistance; R. Coffin, Cavenish Farms, and C. Thompson, Idaho Crop Improvement Association, Inc., for potato leaf samples; and Richard Anderson, Alain Boucher, and Paul Milburn for reviewing the manuscript.

\section{LITERATURE CITED}

1. Bartels, R. 1971. Potato Virus A. Descriptions of Plant Viruses No. 54. CMI/AAB, U.K.

2. Beemster, A. B. R., and de Bokx, J. A. 1987. Survey of properties and symptoms. Pages 84-113 in: Viruses of Potato and Seed Potato Production. J. A. de Bokx and J. P. H. van der Want, eds. Pudoc, Wageningen.

3. Colinet, D., Kummert, P, Lepoivre, P., and Semal, J. 1994. Identification of distinct potyviruses in mixedly infected sweet potato by the polymerase chain reaction with degenerate primers. Phytopathology 84:65-69.

4. Dekker, E. L., Derks, A. F. L., Asjes, C. J., Lemmers, M. E. C., Bol, J. F., and Langeveld, S. A. 1993. Characterization of potyvirus from tulip and lily which cause flowerbreaking. J. Gen. Virol. 74:881-887.

5. Gibbs, A., and MacKenzie, A. 1997. A primer pair for amplifying part of the genome of all potyvirids by RT-PCR. J. Virol. Methods 63:9-16.

6. Hadidi, A., Levy, L., and Podleckis, E. V. 1995. Polymerase chain reaction technology in plant pathology. Pages 167-187 in: Molecular Methods in Plant Pathology. R. P. Singh and U. S. Singh, eds. CRC/Lewis Press, Boca Raton.

7. Henson, J. M., and French, R. 1993. The polymerase chain reaction and plant disease diagnosis. Annu. Rev. Phytopathol. 331:81109.

8. Langeveld, S. A., Dore, J.-M., Memelink, J., Derks, A. F. L. M., van der Vlugt, C. I. M., Asjes, C. J., and Bol., J. F. 1991. Identification of potyviruses using the polymerase chain reaction with degenerate primers. J. Gen. Virol. 72:1531-1541.

9. MacLachlan, D. S., Larson, R. H., and Walker, J. C. 1954. Potato virus A. Am. Potato J. 31:67-72.

10. Petrunak, D. M., Gildow, F. E., and Christ, B. J. 1991. Incidence and distribution of six viruses infecting potatoes in Pennsylvania. Plant Dis. 75:644.

11. Puttrand, Ü., MäKinen, K., Paulin, L., and Saarma, M. 1994. The nucleotide sequence of 
potato virus A genomic RNA and its sequence similarities with other potyviruses. J. Gen. Virol. 75:457-461.

12. Shamloul, A. M., Hadidi, A., Zhu, S. F., Singh, R. P., and Sagredo, B. 1997. Sensitive detection of potato spindle tuber viroid using RT-PCR and identification of a viroid variant naturally infecting pepino plants. Can. J. Plant Pathol. 19:89-96.

13. Singh, M., and Singh, R. P. 1995. Digoxigenin-labeled cDNA probes for the detection of potato virus $\mathrm{Y}$ in dormant potato tubers. $\mathrm{J}$. Virol. Methods 52:133-143.

14. Singh, M., and Singh, R. P. 1996. Factors affecting detection of PVY in dormant tubers by reverse transcription polymerase chain reaction and nucleic acid spot hybridization. $\mathrm{J}$. Virol. Methods 60:47-57.

15. Singh, M., and Singh, R. P. 1996. Nucleotide sequence and genome organization of a Canadian isolate of the common strain of potato virus Y $\left(\mathrm{PVY}^{\mathrm{O}}\right)$. Can. J. Plant Pathol. 18:209224.

16. Singh, M., and Singh, R. P. 1997. Potato virus Y detection: sensitivity of RT-PCR depends on the size of fragment amplified. Can. J. Plant Pathol. 19:149-155.
17. Singh, R. P. 1982. Physalis angulata as a local lesion host for postharvest indexing of potato virus A. Plant Dis. 66:1151-1152.

18. Singh, R. P., and Boiteau, G. 1987. Control of aphid borne diseases: nonpersistent viruses. Pages 30-53 in: Potato Pest Management in Canada. G. Boiteau, R. P. Singh, and R. H. Parry, eds. Proc. Symp. Improving Potato Pest Protection, January 27-29, 1987.

19. Singh, R. P., Boucher, A., Somerville, T. H., and Dhar, A. K. 1993. Selection of a monoclonal antibody to detect $\mathrm{PVY}^{\mathrm{N}}$ and its use in ELISA and DIBA assays. Can. J. Plant Pathol. 15:293-300.

20. Singh, R. P., Drew, M. E., Smith, E. M., and Bagnall, R. H. 1979. Potato virus A lesions on Physalis species. Am. Potato J. 56:367-371.

21. Singh, R. P., Kurz, J., and Boiteau, G. 1996 Detection of stylet-borne and circulative potato viruses in aphids by duplex reverse transcription polymerase chain reaction. J. Virol. Methods 59:189-196.

22. Singh, R. P., Kurz, J., Boiteau, G., and Bernard, G. 1995. Detection of potato leafroll virus in single aphids by the reverse transcription polymerase chain reaction and its potential epidemiological application. J. Virol.
Methods 55:133-143.

23. Singh, R. P., and McDonald, J. G. 1981 Purification of potato virus A and its detection in potato by enzyme-linked immunosorbent assay (ELISA). Am. Potato J. 58:180-186.

24. Thomson, D., and Dietzgen, R. G. 1995. Detection of DNA and RNA plant viruses by PCR and RT-PCR using rapid virus release protocol without tissue homogenization. J. Virol. Methods 54:85-95

25. Tordo, V. M.-J., Chachulska, A. M Fakhfakh, H., LeRomancer, M., Robaglia, C. and Astier-Manifacier, S. 1995. Sequence polymorphism in the $5^{\prime}-\mathrm{NTR}$ and in the P1 coding region of potato virus $\mathrm{Y}$ genomic RNA. J. Gen. Virol. 76:939-949.

26. Vetten, H. J., Ehlers, U., and Paul, H. L. 1983. Detection of potato virus $\mathrm{Y}$ and $\mathrm{A}$ in tubers by enzyme-linked immunosorbent assay after natural and artificial break of dormancy. J. Phytopathol. 108:41-53.

27. Vunsh, R. A., Rosner, A., and Stein, A. 1990. The use of the polymerase chain reaction (PCR) for the detection of bean yellow mosaic virus in gladiolus. Ann. Appl. Biol. 117:561-569. 